\title{
Risk Markers for Not Returning to Work Among Patients with Acquired Brain Injury: A Population-Based Register Study
}

\author{
Marie Matérne ${ }^{1,3}$ (D) $\cdot$ Thomas Strandberg ${ }^{2,3} \cdot$ Lars-Olov Lundqvist ${ }^{1,2,3}$
}

Published online: 4 March 2019

(c) The Author(s) 2019

\begin{abstract}
Purpose The aim of this study is to investigate person-related, injury-related, activity-related and rehabilitation-related risk markers for not return to work among patients with acquired brain injury (ABI). Methods Retrospective data from the Quality register, WebRehab Sweden, on an ABI cohort of 2008 patients, was divided into two groups: those who had returned to work $(n=690)$ and those who had not returned to work $(n=1318)$ within a year of the injury. Results Risk ratio analyses showed that several factors were risk markers for not returning to work: personal factors, including being a woman, being born outside of Sweden, having a low education level, and not having children in the household; injury-related factors, including long hospital stay (over 2 months), aphasia, low motor function, low cognitive function, high pain/discomfort, and high anxiety/depression; activity-related factors, including low function in self-care, inability to perform usual activities, and not having a driver's license; and rehabilitation-related factors, including being dissatisfied with the rehabilitation process and the attentiveness of the staff having limited influence over the rehabilitation plan, or not having a rehabilitation plan at all. Conclusion Several factors in different aspects of life were risk markers for not returning to work among patients with ABI. This suggests that rehabilitation and interventions need to address not only direct injury-related issues, but also personrelated, activity-related, and rehabilitation-related factors in order to increase the patient's opportunities to return to work.
\end{abstract}

Keywords Brain Injuries $\cdot$ Return to work $\cdot$ Rehabilitation, vocational $\cdot$ Employment $\cdot$ Registries

\section{Introduction}

One of the main causes of disability worldwide is acquired brain injury (ABI), which may result from cerebrovascular accidents, infections, toxins, tumors, or trauma to the brain [1-5]. Most people with ABI want to live a normal everyday life after the injury, such as returning to work, earning their subsistence and participating in society [6]. However, for many individuals with $\mathrm{ABI}$ it is a challenge to return to work. In Sweden, approximately 26,500 people are affected by stroke annually [7], a further 14,000 are treated in hospital for traumatic brain injury, but there are also hidden

Marie Matérne

marie.materne@ regionorebrolan.se

1 University Health Care Research Center, Faculty of Medicine and Health, Örebro University, Örebro, Sweden

2 School of Law, Psychology and Social Work, Örebro University, Örebro, Sweden

3 The Swedish Institute for Disability Research, Örebro University, Örebro, Sweden statistics to consider [8]. Each year, approximately 1300 people with different tumors in the brain are also diagnosed [9] and finally there are other kind of ABI caused by diseases. For people with $\mathrm{ABI}$, vocational rehabilitation is often a long process [10] and, in Sweden, only 35-41\% of them have returned to work after 2-3 years $[4,5]$. This is in line with international findings showing that about $40 \%$ of individuals with an ABI return to work within 2 years [11]. Thus, the probability of returning to work after an $\mathrm{ABI}$ is generally low, which influences both the individual and the society. Several factors have been identified as associated with return to work among people with ABI. In the present study, we have categorized the factors into four areas: person-related factors, injury-related factors, activity-related factors and rehabilitation-related factors.

Regarding the person-related factors age $[3,12,13]$ and gender $[3,12,14-16]$, older people $[3,12,13]$ and women $[3,12,14-16]$ have a higher risk of not returning to work after ABI. Education is another important area, in that having a low education level [17-19] increases the risk of not returning to work. For instance, it has been shown 
that patients without a university degree are 2.3 times less likely to return to work than university graduates [20]. Others have shown that younger patients with stroke who had a university degree were $13 \%$ more likely to return to work than those without a university degree [19]. In addition, the individual's social network is important, for instance being married was found in one study to be a positive predictor for returning to work [21], although others have not found any association between marital status and returning to work [3]. Patients who are less motivated [22, 23], who do not emotionally accept their disability [24], who are inflexible and unrealistic in their vocational goals, or who have a more avoidant coping style [14] are less likely to return to work. Moreover, how patients talk about and understand (or do not understand) their rehabilitation and return-to-work process can influence their opportunities to return to work [25].

In regard to injury-related factors, particularly those related to the degree of injury, such as multiple bodily injuries [16], low physical ability [3, 5, 12, 14, 15, 26-30], and a prolonged stay in hospital $[13-15,17,24,31]$ are significant predictors for taking a longer time to return to work. Moreover, being diagnosed with depression [14, 15, 26], having low cognitive ability $[5,23,26]$, and the presence of fatigue [32-34] are all associated with worse return-to-work outcomes.

Concerning activity-related factors, such as performing activities of daily living independently at admission to hospital for a first stroke, were associated with a three times higher chance of returning to work early than for individuals who were totally dependent on others for activities of daily living [3]. One study on cardiac arrest [35] showed that those who were discharged to their own homes had fewer neurological deficits, were more able to handle activities of daily living, had fewer cognitive difficulties, and could more easily return to work. Another relevant factor for an independent lifestyle after ABI was transportation, both for community integration and for vocational rehabilitation [36].

About rehabilitation-related factors, research into individual rehabilitation planning, active participation in inpatient care, and how that affects return to work among patients with ABI is scarce. However, studies have shown that patients with neurological, cardiovascular, and respiratory impairments who were included in the planning of their rehabilitation goals were more compliant with the training regime than those who were not included in the planning [37].

In summary, existing research shows that a variety of factors can affect the opportunities for patients with ABI to return to work. Most research has focused mainly on personal and injury-related factors and less on activity and rehabilitation factors. For instance, there is little research concerning how home support, rehabilitation planning, and possessing a driver's license affect return to work for patients with ABI. Also, research into person-related factors affecting return to work, such as being born in another country, partnership status, and having children living at home is warranted. In addition, the legal and social framework of a particular country may have consequences for patients with $\mathrm{ABI}$ and their return to work. Thus, the aim of this study was to investigate person-related, injury-related, activity-related, and rehabilitation-related risk markers for not returning to work among patients with ABI.

\section{Method}

The regional Ethical Review Board in Uppsala, Sweden (ref. 2016/055) approved the study. After ethical approval, an application was sent to the quality register WebRehab Sweden for data access. The application was agreed, and a statistician from the register extracted data and made it available to the researchers.

\section{Study Population}

WebRehab Sweden is a quality register that collects data on brain-injured patients upon admission to hospital, at discharge from hospital, and at follow-up 1 year after the injury [38]. WebRehab Sweden started 1997 and covers $75 \%$ of the rehabilitation medicine clinics in Sweden [38]. Between 1 January 2007 and 15 January 2016 (the data collection period for the present study), the register included a total of 11,346 patients with ABI. The inclusion criteria for the present study were: (1) being 18-66 years old (2) having an ABI (i.e., stroke, subarachnoid hemorrhage, traumatic brain injury, post-infectious/post-inflammatory brain injury, anoxic brain injury, or other brain injury), (3) working 50\% or more (employed or self-employed) at admission to hospital, (4) not working at all at discharge from hospital (i.e., being on $100 \%$ sick leave), and (5) having follow-up data. A total of 2008 patients were included. For a flow chart, see Fig. 1. Those patients who appeared several times in the data file were only included in the study at the first registered injury period. Only those with a maximum hospitalization period of 1 year and a hypothetical chance of returning to work within 1 year were included.

\section{Measures}

\section{Dependent Variable (Outcome)}

Returned to Work This variable was scored as Yes if the patient worked at least $50 \%$, in paid employment or selfemployed, at follow-up 1 year after the injury and No if they were working $<50 \%$ at follow-up. 


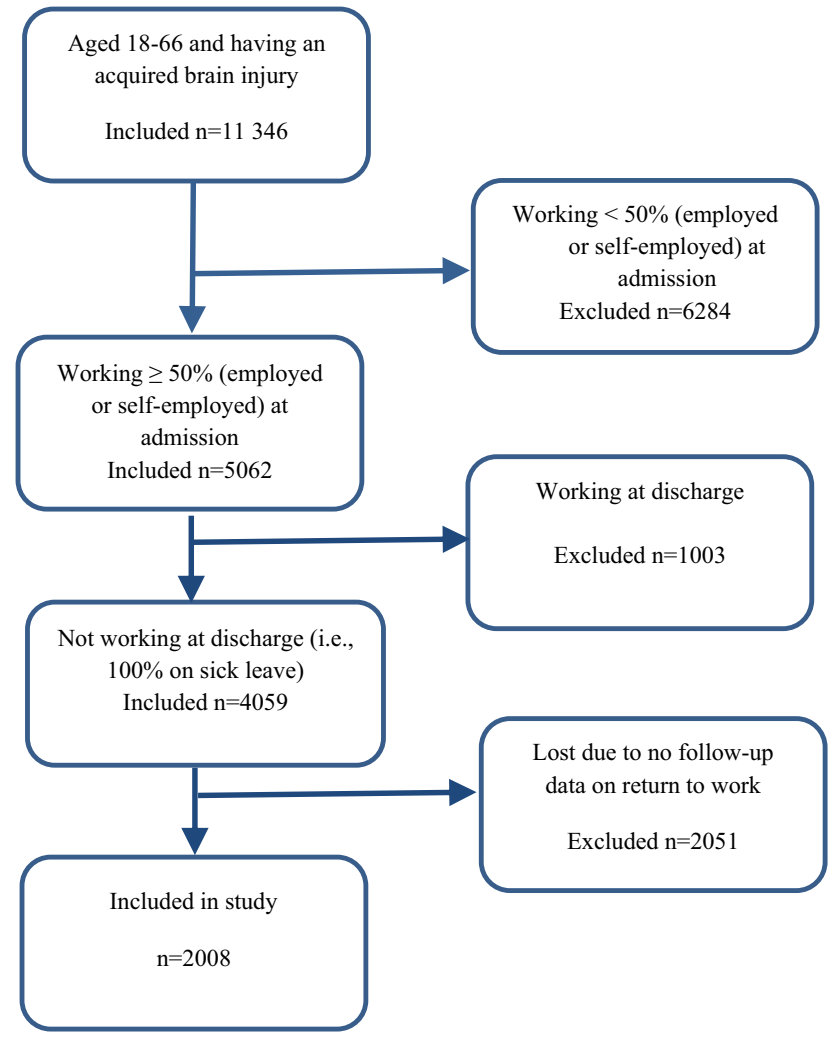

Fig. 1 Flow chart of the inclusion process

\section{Independent Variables (Predictors)}

Demographic Data Demographic data consisted of age (in years) at admission, gender, education (compulsory school, upper secondary school, or university), and country of birth (Sweden or outside Sweden). Hospital stay was measured in days from admission to discharge.

Diagnosis Diagnosis was categorized at admission to hospital into seven groups and in this study rescored into three categories: stroke (stroke and subarachnoid hemorrhage), traumatic brain injury, and other brain injuries (post-infectious/post-inflammatory brain injury, anoxic brain injury, brain tumors, and other brain injuries).

Functional Outcome Functional outcome was measured using the Extended Glasgow Outcome Scale (GOSE) [39]. GOSE assesses overall function after a head injury relative to pre-injury function on a global scale in eight steps [40, 41]. The scores range from dead (I), vegetative state (II), lower severe disability (III), upper severe disability (IV), lower moderate disability (V), upper moderate disability (VI), lower good recovery (VII), and upper good recovery (VIII). In this study, the eight GOSE levels were rescored into three categories, with GOSE category I-IV labeled as poor recovery, category $\mathrm{V}-\mathrm{VI}$ as moderate recovery, and category VII-VIII as good recovery.

Motor and Cognitive Function Motor and cognitive function was measured using the Functional Independence Measure (FIM) [42, 43]. FIM is categorized into 18 activities. Each of the activities is scored from 1 (total need of assistance) to 7 (complete independence). These activities are grouped into six areas of function: (I) self-care, (II) sphincter control, (III) mobility, (IV) locomotion, (V) communication, and (VI) social cognition [42, 43]. FIM is assessed by observing the patient [42]. The activities in category I-IV measure motor function and the activities in category $\mathrm{V}$ and VI measure cognitive function. In the present study, the motor function and cognitive function mean scores were rescored into three levels: total assistance (a mean score from 1.00 to 2.99), some help needed (a mean score from 3.00 to 5.99), and no help needed (a mean score from 6.00 to 7.00).

Partnership Status and Having Children Living at Home The register contains seven categories for the household variable, confounding 'marital status' and 'having children'. These variables were rescored into two new variables: Being single (Yes or No) and having children living at home (Yes or No), the alternatives "don't know" and "other" were excluded from analysis.

Home Support In the register, the housing variable included a mix of accommodation types (ordinary or special) and support in the home (support and no support). This variable was rescored into a new Home support variable scored as those with support (Yes) and those without support (No), regardless of type of accommodation.

Driver's License Having a driver's license at discharge was scored as Yes if the patient still had one, and No if the license had been suspended or the patients never had any.

Individual Rehabilitation Plan This tool outlines the intended rehabilitation process for the individual patient. The plan is established jointly with the patient, health care representatives, the municipality, the relatives, and the employer [44]. The aim of the plan is to increase the patient's participation in his or her rehabilitation process. The WebRehab register contains two questions on this topic: 'Has a written rehabilitation plan been prepared?', scored as No or Yes and 'Has a written rehabilitation plan been used?', scored as Not used or Yes/partly used.

Satisfaction with the Rehabilitation The register also contains a patient-reported experience measure (PREM) with seven questions regarding the patient's degree of satisfaction with (1) the attention received from the staff, (2) the 
cooperation with the staff, (3) the rehabilitation process, (4) the patient's influence over the rehabilitation process, including the individual rehabilitation plan, (5) the information given about the brain injury, (6) the information given on where to get more support if needed after discharge from hospital, and (7) the information and attention the family and relatives had received during the patient's rehabilitation at the clinic. Each question was scored on a four-point Likert scale from 'very dissatisfied' to 'very satisfied'. In the present study, the responses 'very dissatisfied' and 'dissatisfied' were rescored as dissatisfied and the responses 'satisfied' and 'very satisfied' were rescored as satisfied. There was also a 'don't know' alternative, which was excluded from the analyses.

Health Status This was measured by five questions covering mobility, self-care, usual activities (e.g. work, studies, household chores, family and leisure activities), pain/discomfort, and anxiety/depression. The questions were taken from the EuroQol five dimensions questionnaire, EQ-5D [45]. Each question was scored in three levels: severe problems, some problems, and no problems. In this study, the questions were treated as individual variables.

\section{Statistical Analyses}

All data analysis was performed using IBM SPSS Statistics version 22.0 (IBM Corp., Armonk, NY, USA). Descriptive statistics (mean and standard deviation) were used to characterize the sample. The risk ratio (RR) and its $95 \%$ confidence interval (CI) for returning to work was estimated for each of the predictor variables using the Chi square test with Fisher's exact test. A p value of 0.05 or less was regarded as statistically significant.

\section{Results}

As shown in Fig. 1, the analyses are based on 2008 patients. Of these, 690 had returned to work and 1318 had not returned to work at follow-up 1 year after the injury. Baseline characteristics of the study sample are shown in Table 1.

The risk ratios for not returning to work are given in Table 2. The results showed that, among the person-related factors, being a woman, being born outside Sweden, having a lower educational level, and not having children in the household increased the risk of not returning to work. Among the brain injury-related factors, a hospital stay of more than 25 days increased the risk of not returning to work. In addition, those with aphasia had a larger risk of not returning to work than those without aphasia. Concerning motor and cognitive functions measured by the FIM, those classified as needing total assistance or some help needed had a higher risk of not returning to work than those who did not need help. Both those with moderate disability and those with poor recovery according to the GOSE measure had a greater risk of not returning to work than those with good recovery. In addition, those who were confined to bed or had problems with mobility were less likely to return to work. Furthermore, patients who had pain/discomfort or anxiety/ depression had a higher risk of not returning to work compared to those with no pain/discomfort or anxiety/depression problems. There was no significant difference in the risk of not returning to work in relation to the type of brain injury diagnosis.

Concerning the activity-related factors, patients with low ability to perform self-care or usual everyday activities had a higher risk of not returning to work than those who had no problems with these activities. Having one's driver's license suspended at discharge also increased the risk of not returning to work. The presence or absence of home support was not a significant risk marker for not returning to work.

Concerning rehabilitation-related factors, the patients' satisfaction with the information they received about the brain injury, information to the family, information on where to turn with questions related to the brain injury after discharge from the hospital, and the cooperation with the staff, were unrelated to the risk of not returning to work. However, being satisfied with the rehabilitation process and being satisfied with their own influence over the rehabilitation planning process were associated with a higher likelihood of returning to work. Contrary to expectations, having a rehabilitation plan increased the risk of not returning to work. Finally, neither the patients' satisfaction with the attention from staff or whether an existing written rehabilitation plan had actually been used were significantly related to the risk of not returning to work.

\section{Discussion}

The purpose of this study was to investigate risk markers for not returning to work among patients with ABI. The main result showed that several factors influence the risk of not returning to work. In keeping with previous research, women had a greater risk of not returning to work within a year after a brain injury compared to men [3, 12, 14-16]. In Sweden, almost as many women as men participate in the workforce [46]. Nevertheless, women in Sweden may still be discriminated in working life; for example, gender norms that exist within a specific workplace could make returning to work harder for women with ABI [47].

The results showed that individuals born outside Sweden had higher risk of not returning to work than those born in Sweden. Statistics Sweden report that people born in Sweden have a working rate of $84 \%$ while people born outside 
Table 1 Baseline characteristics at admission of persons who returned to work (RTW; $n=690$ ) or did not return to work (non-RTW; $\mathrm{n}=1318$ ) within 357 days after acquired brain injury

\begin{tabular}{|c|c|c|c|}
\hline Variables & $\begin{array}{l}\text { Total } \\
\mathrm{N}=2008(100 \%)\end{array}$ & $\begin{array}{l}\text { Non- RTW } \\
\mathrm{N}=1318(66 \%)\end{array}$ & $\begin{array}{l}\text { RTW } \\
N=690(34 \%)\end{array}$ \\
\hline \multicolumn{4}{|l|}{ Person-related factors } \\
\hline Age group (mean 51.02; SD 10.41) & $2008(100)$ & $1318(100)$ & $690(100)$ \\
\hline $18-29$ & $129(7)$ & $76(6)$ & $53(8)$ \\
\hline $30-39$ & $181(9)$ & $112(9)$ & $69(10)$ \\
\hline $40-49$ & $458(23)$ & $302(23)$ & $156(23)$ \\
\hline $50-59$ & $896(45)$ & $604(46)$ & $291(42)$ \\
\hline $60-66$ & $345(17)$ & 224 (17) & $121(18)$ \\
\hline Gender & $2008(100)$ & $1318(100)$ & $690(100)$ \\
\hline Man & $1278(64)$ & $787(60)$ & $491(71)$ \\
\hline Woman & $730(36)$ & $531(40)$ & $199(29)$ \\
\hline Country of birth & $1248(100)$ & $785(100)$ & $463(100)$ \\
\hline Sweden & $1099(88)$ & $667(85)$ & $432(93)$ \\
\hline Outside Sweden & $149(12)$ & $118(15)$ & $31(7)$ \\
\hline Education & $1180(100)$ & $743(100)$ & $437(100)$ \\
\hline Compulsory school (9 years of education) & $117(10)$ & $79(11)$ & $38(8)$ \\
\hline Upper secondary school ( $<12$ years of education) & $653(55)$ & $439(59)$ & $214(50)$ \\
\hline University (> 12 years of education) & $410(35)$ & $225(30)$ & $185(42)$ \\
\hline Marital status & $1918(100)$ & $1254(100)$ & $664(100)$ \\
\hline Single & $643(34)$ & $424(34)$ & $219(33)$ \\
\hline Living with a partner & $1275(66)$ & $830(66)$ & $445(67)$ \\
\hline Children & $1918(100)$ & $1254(100)$ & $664(100)$ \\
\hline No children in household & $1310(68)$ & $878(70)$ & $432(65)$ \\
\hline Children in household & $608(32)$ & $376(30)$ & $232(35)$ \\
\hline \multicolumn{4}{|l|}{ Injury-related factors } \\
\hline Diagnosis & $2008(100)$ & $1319(100)$ & $690(100)$ \\
\hline Stroke & $1476(73)$ & $986(75)$ & $490(71)$ \\
\hline TBI & $336(17)$ & $206(16)$ & $130(19)$ \\
\hline Other kind of brain injury & $196(10)$ & $126(9)$ & $70(10)$ \\
\hline Aphasia/dysphasia & $1312(100)$ & $885(100)$ & $427(100)$ \\
\hline No & $981(75)$ & $630(71)$ & $351(82)$ \\
\hline Yes & $331(25)$ & $255(29)$ & $76(18)$ \\
\hline Hospital stay (mean 52.34 days; SD 42.87) & $2008(100)$ & $1317(100)$ & $690(100)$ \\
\hline Short (0-24 days) & $537(27)$ & 224 (17) & $313(45)$ \\
\hline Moderate (25-68 days) & $943(47)$ & $625(47)$ & $318(46)$ \\
\hline Long (68-357 days) & $528(26)$ & $469(36)$ & $59(9)$ \\
\hline Functional outcome & $1400(100)$ & $912(100)$ & $488(100)$ \\
\hline Good recovery (VII-VIII) & $308(22)$ & $127(14)$ & $181(37)$ \\
\hline Moderate disability (V-VI) & $824(59)$ & $543(60)$ & $281(58)$ \\
\hline Very severe and severe disability (I-IV) & $268(19)$ & $242(26)$ & $26(5)$ \\
\hline Motor function & $1590(100)$ & $1073(100)$ & $518(100)$ \\
\hline No help needed 6-7 & $1149(72)$ & $684(64)$ & $465(90)$ \\
\hline Some help needed 3-5.99 & $348(22)$ & $302(28)$ & $46(9)$ \\
\hline Total assistance 1-2.99 & $93(6)$ & $86(8)$ & $7(1)$ \\
\hline Cognitive function & $1591(100)$ & $1073(100)$ & $518(100)$ \\
\hline No help needed 6-7 & $986(62)$ & $572(53)$ & $414(80)$ \\
\hline Some help needed 3-5.99 & $533(33)$ & $438(41)$ & $95(18)$ \\
\hline Total assistance $1-2.99$ & $72(5)$ & $63(6)$ & $9(2)$ \\
\hline Mobility & $1464(100)$ & $959(100)$ & $505(100)$ \\
\hline
\end{tabular}


Table 1 (continued)

\begin{tabular}{|c|c|c|c|}
\hline Variables & $\begin{array}{l}\text { Total } \\
\mathrm{N}=2008(100 \%)\end{array}$ & $\begin{array}{l}\text { Non- RTW } \\
\mathrm{N}=1318(66 \%)\end{array}$ & $\begin{array}{l}\text { RTW } \\
N=690(34 \%)\end{array}$ \\
\hline I have no problems walking about & $761(52)$ & $404(42)$ & $357(70.5)$ \\
\hline I have some problems walking about & $663(45)$ & $517(54)$ & $146(29)$ \\
\hline I am confined to bed & $40(3)$ & $38(4)$ & $2(0.5)$ \\
\hline Pain/discomfort & $1464(100)$ & $959(100)$ & $505(100)$ \\
\hline I have no pain or discomfort & $623(42)$ & $358(37)$ & $265(52)$ \\
\hline I have moderate pain or discomfort & $771(53)$ & $545(57)$ & $226(45)$ \\
\hline I have extreme pain or discomfort & $70(5)$ & $56(6)$ & $14(3)$ \\
\hline Anxiety/depression & $1464(100)$ & $959(100)$ & $505(100)$ \\
\hline I am not anxious or depressed & $809(55)$ & $468(49)$ & $341(67)$ \\
\hline I am moderately anxious or depressed & $610(42)$ & $455(47)$ & $155(31)$ \\
\hline I am extremely anxious or depressed & $45(3)$ & $36(4)$ & $9(2)$ \\
\hline \multicolumn{4}{|l|}{ Activity-related factors } \\
\hline Self-care & $1464(100)$ & $959(100)$ & $505(100)$ \\
\hline I have no problems with self-care & $1092(75)$ & $640(67)$ & $452(89)$ \\
\hline I have some problems washing or dressing myself & $327(22)$ & $278(29)$ & $49(10)$ \\
\hline I am unable to wash or dress myself & $45(3)$ & $41(4)$ & $4(1)$ \\
\hline Usual activities & $1464(100)$ & $959(100)$ & $505(100)$ \\
\hline I have no problems with performing my usual activities & $459(31)$ & $231(24)$ & $228(45)$ \\
\hline I have some problems with performing my usual activities & 709 (49) & $493(51)$ & $216(43)$ \\
\hline I am unable to perform my usual activities & $296(20)$ & $235(25)$ & $61(12)$ \\
\hline Driver's license & $1909(100)$ & $1250(100)$ & $659(100)$ \\
\hline No & $1762(93)$ & $1167(93)$ & $595(90)$ \\
\hline Yes & $147(7)$ & $83(7)$ & $64(10)$ \\
\hline Home support & $259(100)$ & $152(100)$ & $107(100)$ \\
\hline Accommodation without support & $244(94)$ & $140(92)$ & $104(97)$ \\
\hline Accommodation with support & $15(6)$ & $12(8)$ & $3(3)$ \\
\hline \multicolumn{4}{|l|}{ Rehabilitation-related factors } \\
\hline The rehabilitation process & $1427(100)$ & $932(100)$ & $495(100)$ \\
\hline Dissatisfied & $16(1)$ & $16(2)$ & $0(0)$ \\
\hline Satisfied & $1411(99)$ & $916(98)$ & $495(100)$ \\
\hline The individual's cooperation with the staff & $897(100)$ & $2(100)$ & $895(100)$ \\
\hline Dissatisfied & $556(62)$ & $2(100)$ & $554(62)$ \\
\hline Satisfied & $341(38)$ & $0(0)$ & $341(38)$ \\
\hline $\begin{array}{l}\text { The individual's influence over the rehabilitation process including his or her rehabilita- } \\
\text { tion plan }\end{array}$ & $857(100)$ & $533(100)$ & $324(100)$ \\
\hline Dissatisfied & $27(3)$ & $24(4)$ & $3(1)$ \\
\hline Satisfied & $830(97)$ & $509(96)$ & $321(99)$ \\
\hline The information given about the brain injury & $1411(100)$ & $911(100)$ & $499(100)$ \\
\hline Dissatisfied & $85(6)$ & $63(7)$ & $22(4)$ \\
\hline Satisfied & $1325(94)$ & $848(93)$ & $477(96)$ \\
\hline The information on where to get support if needed after discharge from hospital & $1268(100)$ & $821(100)$ & $447(100)$ \\
\hline Dissatisfied & $66(5)$ & $49(6)$ & $17(4)$ \\
\hline Satisfied & $1202(95)$ & $772(94)$ & $430(96)$ \\
\hline The attention given to the individual by the staff & $1446(100)$ & $942(100)$ & $505(100)$ \\
\hline Dissatisfied & $11(1)$ & $10(1)$ & $1(1)$ \\
\hline Satisfied & 1435 (99) & $931(99)$ & $504(99)$ \\
\hline Has a written rehabilitation plan been prepared? & $2008(100)$ & $1318(100)$ & $690(100)$ \\
\hline No & $214(11)$ & $116(9)$ & $98(14)$ \\
\hline Yes & $1794(89)$ & $1202(91)$ & $592(86)$ \\
\hline
\end{tabular}


Table 1 (continued)

\begin{tabular}{|c|c|c|c|}
\hline Variables & $\begin{array}{l}\text { Total } \\
\mathrm{N}=2008(100 \%)\end{array}$ & $\begin{array}{l}\text { Non- RTW } \\
\mathrm{N}=1318(66 \%)\end{array}$ & $\begin{array}{l}\text { RTW } \\
\mathrm{N}=690(34 \%)\end{array}$ \\
\hline Has a written rehabilitation plan been used? & $1799(100)$ & $1205(100)$ & $594(100)$ \\
\hline No & $12(0.5)$ & $5(0.5)$ & $7(1)$ \\
\hline Yes & $1787(99.5)$ & $1200(99.5)$ & $587(99)$ \\
\hline $\begin{array}{l}\text { The information and attention the family and relatives had received during the individu- } \\
\text { al's rehabilitation at the clinic }\end{array}$ & $828(100)$ & $514(100)$ & $314(100)$ \\
\hline Dissatisfied & $19(2)$ & $13(2)$ & $6(2)$ \\
\hline Satisfied & $809(98)$ & $501(98)$ & $308(98)$ \\
\hline
\end{tabular}

Sweden have a rate of $71 \%$ [48]. No studies about immigrants with ABI, and return to work were found, but a study on low back pain compared native-born patients and immigrants entering rehabilitation noted that immigrants might have special needs that should be addressed when planning rehabilitation [49] which also may be the case for patients with ABI.

The results showed that a high education level was essential for returning to work. Having a university degree increased the chances of returning to work after an ABI, something that has also has been found by others [17-19]. An explanation is that a university degree gives a wider range of possible job assignments. In our study, $45 \%$ of the individuals with a university degree returned to work, but only $32 \%$ of those with compulsory school education returned to work. A higher education level generally predicts higher income and higher socioeconomic status [19]. Higher education is also often associated with white-collar jobs, and these positions are often more flexible [5, 24, 50]. Therefore, giving the patients the possibility of education during the rehabilitation period could be a positive factor for at least some of these patients, but the education would have to be adapted to the patient's individual capacity.

Those in households with children had a significantly higher likelihood of returning to work than those in households without children. No other research findings have been found in this area, but children in the household can be a driving force [51]. Returning to working life makes it possible to show the children that everything is normal again after the injury. Financial needs may also be a driving force for return to work.

Moreover, it has been argued that living in a relationship provides a natural support system for an individual with brain injury [21], but, in our study, being married or living with a partner was not associated with a higher likelihood of returning to work, and similar results has been found by other studies [3, 52]. Nevertheless, there are some findings that indicate that marriage may be a positive predictor for returning to work [21] and others have shown that support from family is important for patients with brain injuries on returning to work $[53,54]$.
The present study did not find age to be a risk marker for not returning to work. This is contrary to previous findings, that younger stroke patients could more easily return to work because they had less indicators of stroke severity, such as hypertension or diabetes prior to their stroke [12].

In regard to injury-related factors, patients with lower motor function showed a higher risk of not returning to work, which is in line with findings in many other studies $[3,5,12,14,15,26-30]$. Those who needed some help with cognitive function (FIM) and those who needed total assistance had a higher risk of not returning to work. The patients who had problems with cognition, continually needed cognitive support, and required help at work had a more complex return-to-work process, as shown in several other studies $[5,23,26]$.

A long period of hospital stay was another risk marker for not returning to work. Those with a longer stay in hospital had a many times higher risk of not returning to work than those with a shorter hospital stay. Several other studies have found a similar result $[13-15,17,24,31]$. Some of them explained that the longer stay in hospital was found with patients who had a more severe injury, making it harder to return to work [15, 17, 24, 31].

Patients with aphasia had a higher risk of not returning to work than those without aphasia. A review showed that employment decreased after aphasia and return to work was often at a less demanding level [55]. Patients with aphasia experienced that it was a struggle to handle activities of daily living and that their aphasia had an impact on their participation in society [56].

Those with moderate or extreme pain/discomfort had higher risk of not returning to work than those without pain/ discomfort. This is in line with previous research, which showed that severe head and/or bodily pain after mild traumatic brain injury predicted a delayed return to work [57]; this is possibly also the case for patients with other kinds of ABI. Finally, our results showed that it was harder to return to work if the patient also suffered from anxiety or depression, which is in keeping with other studies [14, 15, 26].

There was, however, no increased risk of not returning to work in relation to type of diagnosis, indicating that the 
Table 2 Relative risk (RR) of not returning to work after acquired brain injury

\begin{tabular}{|c|c|c|c|}
\hline Variables & $\begin{array}{l}\text { RR of not } \\
\text { returning to } \\
\text { work }\end{array}$ & $\begin{array}{l}95 \% \\
\text { confidence } \\
\text { interval }\end{array}$ & $\mathrm{P}^{\mathrm{a}}$ \\
\hline \multicolumn{4}{|l|}{ Person-related factors } \\
\hline \multicolumn{4}{|l|}{ Age group } \\
\hline $18-29$ & Ref & Ref & \\
\hline $30-39$ & 1.05 & $0.87-1.28$ & 0.638 \\
\hline $40-49$ & 1.07 & $0.98-1.18$ & 0.146 \\
\hline $50-59$ & 1.05 & $1.00-1.11$ & 0.058 \\
\hline $60-66$ & 1.07 & $0.95-1.21$ & 0.240 \\
\hline \multicolumn{4}{|l|}{ Gender } \\
\hline Man & Ref & Ref & \\
\hline Woman & 1.40 & $1.22-1.60$ & $<0.001$ \\
\hline \multicolumn{4}{|l|}{ Country of birth } \\
\hline Sweden & Ref & Ref & \\
\hline Outside Sweden & 2.25 & $1.54-3.28$ & $<0.001$ \\
\hline \multicolumn{4}{|l|}{ Education } \\
\hline Compulsory school (9 years) & Ref & Ref & \\
\hline Upper secondary school ( $\leq 12$ years) & 1.00 & $0.94-1.06$ & 1.000 \\
\hline University (> 12 years) & 0.89 & $0.82-0.98$ & 0.015 \\
\hline \multicolumn{4}{|l|}{ Marital status } \\
\hline Single & Ref & Ref & \\
\hline Partnership & 0.99 & $0.93-1.06$ & 0.722 \\
\hline \multicolumn{4}{|l|}{ Children } \\
\hline No children in household & Ref & Ref & \\
\hline Children in household & 0.86 & $0.75-0.98$ & 0.030 \\
\hline \multicolumn{4}{|l|}{ Injury-related factors } \\
\hline \multicolumn{4}{|l|}{ Diagnosis } \\
\hline Stroke & Ref & Ref & \\
\hline TBI & 0.82 & $0.68-1.00$ & 0.056 \\
\hline Other kind of brain injury & 0.91 & $0.69-1.19$ & 0.519 \\
\hline \multicolumn{4}{|l|}{ Aphasia/dysphasia } \\
\hline No & Ref & Ref & \\
\hline Yes & 1.62 & $1.29-2.04$ & $<0.001$ \\
\hline \multicolumn{4}{|l|}{ Hospital stay } \\
\hline Short (0-24.99 days) & Ref & Ref & \\
\hline Moderate (25-68.99 days) & 1.46 & $1.34-1.59$ & $<0.001$ \\
\hline Long (69-357 days) & 4.27 & $3.36-5.42$ & $<0.001$ \\
\hline \multicolumn{4}{|l|}{ Functional outcome } \\
\hline Good recovery VII-VIII & Ref & Ref & \\
\hline Moderate disability V-VI & 1.33 & $1.23-1.45$ & $<0.001$ \\
\hline Very severe and severe disability I-IV & 5.22 & $3.62-7.54$ & $<0.001$ \\
\hline \multicolumn{4}{|l|}{ Motor function } \\
\hline No help needed (6.00-7.00) & Ref & Ref & \\
\hline Some help needed (3.00-5.99) & 3.40 & $2.54-4.55$ & $<0.001$ \\
\hline Total assistance (1.00-2.99) & 7.53 & $3.52-16.13$ & $<0.001$ \\
\hline \multicolumn{4}{|l|}{ Cognitive function } \\
\hline No help needed (6.00-7.00) & Ref & Ref & \\
\hline Some help needed (3.00-5.99) & 2.32 & $1.91-2.82$ & $<0.001$ \\
\hline Total assistance (1.00-2.99) & 4.66 & $2.35-9.27$ & $<0.001$ \\
\hline \multicolumn{4}{|l|}{ Mobility } \\
\hline I have no problems walking about & Ref & Ref & \\
\hline
\end{tabular}


Table 2 (continued)

\begin{tabular}{|c|c|c|c|}
\hline Variables & $\begin{array}{l}\text { RR of not } \\
\text { returning to } \\
\text { work }\end{array}$ & $\begin{array}{l}95 \% \\
\text { confidence } \\
\text { interval }\end{array}$ & $\mathrm{P}^{\mathrm{a}}$ \\
\hline I have some problems walking about & 1.93 & $1.67-2.24$ & $<0.001$ \\
\hline I am confined to bed & 15.43 & $3.75-63.53$ & $<0.001$ \\
\hline \multicolumn{4}{|l|}{ Pain/discomfort } \\
\hline I have no pain or discomfort & Ref & Ref & \\
\hline I have moderate pain or discomfort & 1.31 & $1.18-1.46$ & $<0.001$ \\
\hline I have extreme pain or discomfort & 2.70 & $1.53-4.75$ & $<0.001$ \\
\hline \multicolumn{4}{|l|}{ Anxiety/depression } \\
\hline I am not anxious or depressed & Ref & Ref & \\
\hline I am moderately anxious or depressed & 1.58 & $1.36-1.83$ & $<0.001$ \\
\hline I am extremely anxious or depressed & 2.78 & $1.36-5.69$ & 0.003 \\
\hline \multicolumn{4}{|l|}{ Activity-related factors } \\
\hline \multicolumn{4}{|l|}{ Self-Care } \\
\hline I have no problems with self-care & Ref & Ref & \\
\hline I have some problems washing or dressing myself & 3.10 & $2.33-4.11$ & $<0.001$ \\
\hline I am unable to wash or dress myself & 6.86 & $2.48-19.03$ & $<0.001$ \\
\hline \multicolumn{4}{|l|}{ Usual activities } \\
\hline I have no problems with performing my usual activities & Ref & Ref & \\
\hline I have some problems with performing my usual activities & 1.40 & $1.26-1.56$ & $<0.001$ \\
\hline I am unable to perform my usual activities & 2.39 & $1.88-3.04$ & $<0.001$ \\
\hline \multicolumn{4}{|l|}{ Driver's license } \\
\hline No & Ref & Ref & \\
\hline Yes & 0.68 & $0.50-0.93$ & 0.019 \\
\hline \multicolumn{4}{|l|}{ Home support } \\
\hline Accommodation without support & Ref & Ref & \\
\hline Accommodation with support & 2.82 & $0.81-9.74$ & 0.107 \\
\hline \multicolumn{4}{|l|}{ Rehabilitation-related factors } \\
\hline \multicolumn{4}{|l|}{ The rehabilitation process } \\
\hline Dissatisfied & Ref & Ref & \\
\hline Satisfied & 0.98 & $0.98-0.99$ & 0.002 \\
\hline \multicolumn{4}{|l|}{ The individual's cooperation with the staff } \\
\hline Dissatisfied & Ref & Ref & \\
\hline Satisfied & 1.00 & $0.99-1.00$ & 0.528 \\
\hline
\end{tabular}

The individual's influence over the rehabilitation process including his or her rehabilitation plan

$\begin{array}{llll}\text { Dissatisfied } & \text { Ref } & \text { Ref } \\ \text { Satisfied } & 0.96 & 0.94-0.99 & 0.004 \\ \begin{array}{l}\text { The information given about the brain injury } \\ \text { Dissatisfied }\end{array} & \text { Ref } & \text { Ref } & \\ \text { Satisfied } & 0.97 & 0.95-1.00 & 0.062\end{array}$

The information on where to turn to get support if needed after discharge from hospital

$\begin{array}{llll}\text { Dissatisfied } & \text { Ref } & \text { Ref } \\ \text { Satisfied } & 0.98 & 0.95-1.00 & 0.112 \\ \text { The attention given to the individual by the staff } & & & \\ \quad \text { Dissatisfied } & \text { Ref } & \text { Ref } & 0.109 \\ \text { Satisfied } & 0.99 & 0.98-1.00 & \\ \text { Has a written rehabilitation plan been prepared? } & & & \\ \text { No } & \text { Ref } & \text { Ref } & \\ \text { Yes } & 1.06 & 1.03-1.10 & \\ \text { Has a written rehabilitation plan been used? } & & & \\ \quad \text { No } & \text { Ref } & & \\ \end{array}$


Table 2 (continued)

\begin{tabular}{|c|c|c|c|}
\hline Variables & $\begin{array}{l}\text { RR of not } \\
\text { returning to } \\
\text { work }\end{array}$ & $\begin{array}{l}95 \% \\
\text { confidence } \\
\text { interval }\end{array}$ & $\mathrm{P}^{\mathrm{a}}$ \\
\hline Yes & 1.01 & $1.00-1.02$ & 0.071 \\
\hline \multicolumn{4}{|c|}{$\begin{array}{l}\text { The information and attention the family and relatives had received during the individual's rehabilita- } \\
\text { tion at the clinic }\end{array}$} \\
\hline Dissatisfied & Ref & Ref & \\
\hline Satisfied & 0.99 & $0.97-1.02$ & 0.639 \\
\hline
\end{tabular}

diagnosis may play a lesser role than the individual's functional level.

Those with poor self-care ability in activities of daily living, such as dressing and washing themselves, had an increased risk of not returning to work. This result is consistent with other studies showing that patients who can independently perform activities of daily living return to work earlier after the injury [3]. In our study, those who had problems with their usual activities, such as studies, household chores, and family and leisure activities, had a higher risk of not returning to work. In addition, those who had their driver's license suspended had a higher risk of not returning to work, which is in line with other findings that having a driver's license was associated with a productive lifestyle after ABI [58]. However, having home support did not influence the risk of not returning to work.

Finally, regarding rehabilitation-related factors satisfaction with the rehabilitation process and the individual's influence over the process, including the individual rehabilitation plan, increased the chances of returning to work. This is in line with other research showing that patients who could understand the rehabilitation were more likely to return to work [25].

One way to help patients understand the rehabilitation is to form a rehabilitation plan that create a predictable vocational rehabilitation process that is transparent for the patient and the staff. However, our results showed, counterintuitively, that having a written rehabilitation plan was associated with a greater risk of not returning to work, regardless of whether this written individual rehabilitation plan was used or not. It may be that patients with minor injuries and a short rehabilitation period are less likely to get a rehabilitation plan and more likely to be able to return to work without needing such support. Another possible explanation is that patients with brain injury have rehabilitation plans from different hospital departments and other organizations that are not coordinated, so the plans that were created have not actually been used or followed up. Future research may shed some light on this result.

Although previous research has shown that information given to the patient and family is an important aspect in the return-to-work process [23], our study found no association between satisfaction with information about the brain injury, satisfaction with information on where to turn for information after the hospitalization period, or satisfaction with the information and attention given to the family and returning to work.

\section{Study Limitations}

Although there are strengths with the study regarding sample size, there are some limitations that have to be addressed, such as the relatively large proportion of missing data. The lack of data is mostly due to the fact that many of the variables were optional for the clinics to assess. As a result, only $18 \%$ of the total cohort could be included in the present study. Another limitation is that there were no data on the exact number of days between discharge from hospital and the time when the patient returned to work, or on what percentage of full-time work they started with and at what point they increased their working hours. Finally, a weakness is that the quality register provides fixed variables, which limits the type of possible research questions [59]. Consequently, in our study, it would have been interesting to examine more rehabilitation-related risk markers as well as risk markers related to adjustments in the vocational rehabilitation process.

\section{Conclusion}

The present study showed that all areas of person-related, injury-related, activity-related, and rehabilitation-related factors are associated with the likelihood of returning to work for patients with ABI. The return-to-work process is complex, with all areas interacting with each other to increase the risk of not returning to work. Most notably, being a woman, being born outside of Sweden, having only a compulsory school diploma, and not having children in the household increased the risk of not returning to work after ABI. Of the injury-related factors, long hospital stay, aphasia, low motor function, low cognitive function, high pain/ discomfort, and high anxiety/depression worsened the chances of returning to work. Of the activity-related factors, 
low function in self-care, low function in usual activities, and low personal influence over the rehabilitation plan also gave a higher risk of not returning to work after ABI. The results show that several factors facilitate return to work, which support previous research proposing individualized work rehabilitation for returning to work after an ABI. Clinical implications for rehabilitation practitioners are therefore to involve patients in individual planning and follow-up on vocational rehabilitation and return to work outcomes.

Acknowledgements We are grateful to WebRehab Sweden for making data available for research. This study was supported by grants from the University Health Care Research Centre, Region Örebro County, Sweden.

\section{Compliance with Ethical Standards}

Conflict of interest The authors declare that they have no conflict of interest.

Open Access This article is distributed under the terms of the Creative Commons Attribution 4.0 International License (http://creativeco mmons.org/licenses/by/4.0/), which permits unrestricted use, distribution, and reproduction in any medium, provided you give appropriate credit to the original author(s) and the source, provide a link to the Creative Commons license, and indicate if changes were made.

\section{References}

1. Campbell M. Rehabilitation for traumatic brain injury: physical therapy practice in context. Edinburgh: Churchill Livingstone; 2000.

2. Andelic N, Stevens LF, Sigurdardottir S, Arango-Lasprilla JC, Roe C. Associations between disability and employment 1 year after traumatic brain injury in a working age population. Brain Inj. 2012;26(3):261-269.

3. Saeki S, Toyonaga T. Determinants of early return to work after first stroke in Japan. J Rehabilit Med. 2010;42(3):254-258.

4. Vestling M, Ramel E, Iwarsson S. Quality of life after stroke: well-being, life satisfaction, and subjective aspects of work. Scand J Occup Ther. 2005;12(2):89-95.

5. Vestling M, Tufvesson B, Iwarsson S. Indicators for return to work after stroke and the importance of work for subjective well-being and life satisfaction. J Rehabilit Med. 2003;35(3):127-131.

6. Saunders $\mathrm{S}, \mathrm{Nedelec} \mathrm{B}$. What work means to people with work disability: a scoping review. J Occup Rehabilit. 2014;24(1):100-110.

7. Socialstyrelsen [The National Board of Health and Welfare]. Statistik om stroke 2016 [Statistics about stroke 2016]. Stockholm; 2017.

8. Socialstyrelsen [The National Board of Health and Welfare]. Statistik om skador och förgiftningar 2014 [Statistics on injuries and poisoning]. Stockholm; 2014.

9. Socialstyrelsen [The National Board of Health and Welfare]. Cancer i siffror [Cancer in numbers]. Stockholm; 2014.

10. Wolfenden B, Grace M. Returning to work after stroke: a review. Int J Rehabilit Res. 2009;32(2):93-97.

11. van Velzen JM, van Bennekom CM, Edelaar MA, Sluiter JK, Frings-Dresen MW. How many people return to work after acquired brain injury? A systematic review. Brain Inj. 2009;23(6):473-488.
12. Busch MA, Coshall C, Heuschmann PU, McKevitt C, Wolfe CDA. Sociodemographic differences in return to work after stroke: the South London Stroke Register (SLSR). J Neurol Neurosurg. 2009;80(8):888-893

13. Hofgren C, Esbjörnsson E, Sunnerhagen KS. Return to work after acquired brain injury: facilitators and hindrances observed in a sub-acute rehabilitation setting. Work: J Prev Assess Rehabilit 2010;36(4):431-439.

14. Arwert HJ, Schults M, Meesters JJL, Wolterbeek R, Boiten J, Vliet Vlieland T. Return to work $2-5$ years after stroke: a cross sectional study in a hospital-based population. J Occup Rehabilit. 2017;27(2):239-246.

15. van Velzen JM, van Bennekom CM, Edelaar MA, Sluiter JK, Frings-Dresen MW. Prognostic factors of return to work after acquired brain injury: a systematic review. Brain Inj. 2009;23(5):385-395.

16. Waljas M, Iverson GL, Lange RT, Liimatainen S, Hartikainen KM, Dastidar P, et al. Return to work following mild traumatic brain injury. J Head Trauma Rehabilit. 2014;29(5):443-450.

17. Donker-Cools B, Wind H, Frings-Dresen M. Prognostic factors of return to work after traumatic or non-traumatic acquired brain injury. Disabil Rehabilit. 2016;38(8):733-741.

18. Treger I, Shames J, Giaquinto S, Ring H. Return to work in stroke patients. Disabil Rehabilit. 2007;29(17):1397-1403.

19. Trygged S, Ahacic K, Kåreholt I. Income and education as predictors of return to working life among younger stroke patients. BMC Public Health. 2011;11(1):742-750.

20. Walker WC, Marwitz JH, Kreutzer JS, Hart T, Novack TA. Occupational categories and return to work after traumatic brain injury: a multicenter study. Arch Phys Med Rehabilit. 2006;87(12):1576-1582.

21. Harris C. Factors influencing return to work after aneurysmal subarachnoid hemorrhage. J Neurosci Nurs. 2014;46(4):207-217.

22. Rubenson C, Svensson E, Linddahl I, Bjorklund A. Experiences of returning to work after acquired brain injury. Scand J Occup Ther. 2007;14(4):205-214.

23. Matérne M, Lundqvist L-O, Strandberg T. Opportunities and barriers for successful return to work after acquired brain injury: a patient perspective. Work. 2017;56(1):125-134.

24. Wang Y-C, Kapellusch J, Garg A. Important factors influencing the return to work after stroke. Work. 2014;47(4):553-597.

25. Landstad BJ, Ahrberg Y. Conceptualizing the driving forces for successful rehabilitation back to work. Disabil Rehabilit 2018;40(15):1781-1790.

26. Fride Y, Adamit T, Maeir A, Ben Assayag E, Bornstein NM, Korczyn $\mathrm{AD}$, et al. What are the correlates of cognition and participation to return to work after first ever mild stroke? Top Stroke Rehabilit. 2015;22(5):317-325.

27. Passier PE, Visser-Meily JM, Rinkel GJ, Lindeman E, Post MW. Life satisfaction and return to work after aneurysmal subarachnoid hemorrhage. J Stroke Cerebrovasc Dis. 2011;20(4):324-329.

28. Gabriele W, Renate S. Work loss following stroke. Disabil Rehabilit. 2009;31(18):1487-1493.

29. Tanaka H, Toyonaga T, Hashimoto H. Functional and occupational characteristics associated with very early return to work after stroke in Japan. Arch Phys Med Rehabilit. 2011;92(5):743-748.

30. Shames J, Treger I, Ring H, Giaquinto S. Return to work following traumatic brain injury: trends and challenges. Disabil Rehabilit. 2007;29(17):1387-1395.

31. Ketchum JM, Almaz Getachew M, Krch D, Banos JH, Kolakowsky-Hayner SA, Lequerica A, et al. Early predictors of employment outcomes 1 year post traumatic brain injury in a population of Hispanic individuals. NeuroRehabilitation. 2012;30(1):13-22. 
32. Kauranen T, Turunen K, Laari S, Mustanoja S, Baumann P, Poutiainen E. The severity of cognitive deficits predicts return to work after a first-ever ischaemic stroke. J Neurol Neurosurg. 2013;84(3):316-321.

33. van Velzen J, van Bennekom C, van Dormolen M, Sluiter J, Frings-Dresen M. Factors influencing return to work experienced by people with acquired brain injury: a qualitative research study. Disabil Rehabilit. 2011;33(23/24):2237-2246.

34. Hartke RJ, Trierweiler R. Survey of survivors' perspective on return to work after stroke. Top Stroke Rehabilit. 2015;22(5):326-334.

35. Hofgren C, Lundgren-Nilsson A, Esbjornsson E, Sunnerhagen KS. Two years after cardiac arrest; cognitive status, ADL function and living situation. Brain Inj. 2008;22(12):972-978.

36. Fraas M, Balz M, DeGrauw W. Meeting the long-term needs of adults with acquired brain injury through community-based programming. Brain Inj. 2007;21(12):1267-1281.

37. Levack WM, Taylor K, Siegert RJ, Dean SG, McPherson KM, Weatherall M. Is goal planning in rehabilitation effective? A systematic review. Clin Rehabilit. 2006;20(9):739-755.

38. Stibrant-Sunnerhagen K, Flansbjer U-B, Lannsjö M, Tölli A, Lundgren-Nilsson A. WebRehab: a Swedish database for quality control in rehabilitation. J Rehabilit Med. 2014;46(10):958-962.

39. Wilson JTL, Pettigrew LEL, Teasdale GM. Structured interviews for the Glasgow Outcome Scale and Extended Glasgow Outcome Scale: guidelines for their use. J Neurotrauma. 1998;15(8):573-584.

40. Jennett B, Snoek J. Disability after severe head injury: observations on the use of the Glasgow Outcome Scale. J Neurol Neurosurg Psychiatry. 1981;44(4):285-293.

41. Teasdale GM, Pettigrew LE, Wilson JT, Murray G, Jennett B. Analyzing outcome of treatment of severe head injury: a review and update on advancing the use of the Glasgow Outcome Scale. J Neurotrauma. 1998;15(8):587-597.

42. Keith RA, Granger CV, Hamilton BB, Sherwin FS. The functional independence measure: a new tool for rehabilitation. Adv Clin Rehabilit. 1987;1:6-18.

43. McDowell I, Newell C. Measuring health - a guide to rating scales and questionnaires. New York: Oxford University Press; 1996.

44. Hälso-och sjukvårdslagen [The Health and Medical Care Act] (2017).

45. EuroQoL group. EuroQoL-a new facility for the measurement of health-related quality of life. Health Policy. 1990;16(3):199-208.

46. Statistics Sweden. Stora skillnader i sysselsättningsgrad mellan småbarnsföräldrar [Large differences in employment rates between parents of small children] [Internet]. 2016 [cited 2018 13/06]. http://www.scb.se/sv_/Hitta-statistik/Statistik-efter-amne/ Arbetsmarknad/Arbetskraftsundersokningar/Arbetskraftsundersok ningarna-AKU/23265/23272/Behallare-for-Press/403978/.

47. Stergiou-Kita M, Mansfield E, Sokoloff S, Colantonio A. Gender influences on return to work after mild traumatic brain injury. Arch Phys Med Rehabilit. 2016;97(2 Suppl):40-45.
48. Statistiska centralbyrån. Mäns och kvinnors arbetsmarknad åren 2001-2016, AM 110 SM 1602 [The labour market for men and women during the years 2001-2016]. Stockholm; 2016.

49. Lindström I, Areskoug B, Allebeck P. Do immigrant patients differ from native Swedish patients with back pain when entering rehabilitation? Adv Physiother. 2002;4(2):74-84.

50. Saeki S, Hachisuka K. The association between stroke location and return to work after first stroke. J Stroke Cerebrovasc Dis. 2004;13(4):160-163.

51. Strandberg T. Vuxna med förvärvad traumatisk hjärnskada omställningsprocesser och konsekvenser i vardagslivet: en studie av femton personers upplevelser och erfarenheter av att leva med förvärvad traumatisk hjärnskada [Adults with acquired traumatic brain injury]. Örebro; 2006.

52. McLean R. Employment status six months after discharge from inpatient rehabilitaiton for a mild-to-moderate physical disability. Ann Acad Med Singap. 2007;36(1):18-21.

53. Nalder E, Fleming J, Cornwell P, Foster M. Linked lives: the experiences of family caregivers during the transition from hospital to home following traumatic brain injury. Brain Impairment. 2012;13(01):108-122.

54. Strandberg T. Adults with acquired traumatic brain injury: experiences of a changeover process and consequences in everyday life. Soc Work Health Care. 2009;48(3):276-297.

55. Dalemans RJP, De Witte LP, Wade DT, Van den Heuvel WJA. A description of social participation in working-age persons with aphasia: a review of the literature. Aphasiology. 2008;22(10):1071-1091.

56. Niemi T, Johansson $\mathrm{U}$. The lived experience of engaging in everyday occupations in persons with mild to moderate aphasia. Disabil Rehabilit. 2013;35(21):1828-1834.

57. Cancelliere C, Kristman VL, Cassidy JD, Hincapié CA, Côté P, Boyle E, et al. Systematic review of return to work after mild traumatic brain injury: results of the International Collaboration on Mild Traumatic Brain Injury Prognosis. Arch Phys Med Rehabilit. 2014;95(Supplement 3):S201-S209.

58. Fraas MR, Calvert M. The use of narratives to identify characteristics leading to a productive life following acquired brain injury. Am J Speech Lang Pathol. 2009;18(4):315-328.

59. Jacobsson Ekman G, Lindahl B, Nordin A. Nationella kvalitetsregister i hälso- och sjukvården [National Quality Register in Health Care]. Stockholm: Karolinska institutet; 2015.

Publisher's Note Springer Nature remains neutral with regard to jurisdictional claims in published maps and institutional affiliations. 